\title{
Tietoteknisten taitojen
}

\section{puutteet maahanmuuttajien kotoutumisen haasteena}

\author{
$+y$ \\ Maahanmuuttajat tarvitsevat tietoteknisiä valmiuksia \\ esimerkiksi digitaalisten viranomaispalvelujen käyttämiseen. \\ Tietoteknisten taitojen hallinta kannattaisi sisällyttää jo \\ alkuvaiheen opetukseen kielenopetuksen rinnalle.
}

DIGITALISOITUVASSA KORKEAN TEKNOLOGIAN Suomessa palvelut ovat siirtyneet yhä enemmän verkkoon, ja työelämän muuttuvat vaatimukset kytkeytyvät vahvasti tietotekniikan soveltamiseen lähes kaikilla aloilla. Tietotekniset perustaidot ovat oppimisen, työllistymisen ja usein myös sosiaalisen osallistumisen edellytyksiä. Koulutuksen ja oppimisen alueelle syntyy jatkuvasti uusia tietokoneperustaisia innovaatioita, joiden osittainenkin hyödyntäminen edellyttää tietoteknisiä perusvalmiuksia, ongelmanratkaisukykyä sekä medialukutaitoja.

Monet arkiset toiminnot, kuten työnhaku, lasten koulunkäynnin seuraaminen ja viranomaisten kanssa asioiminen, hoidetaan verkossa. Viranomaispalvelu- jen käyttäminen edellyttää usein digitaalista tunnistautumista, mikä tapahtuu yleensä pankkitunnuksilla. Esimerkiksi julkisen työnhakujärjestelmän käyttämiseen tarvitaan tunnistautumista sekä digitaalisen järjestelmän ominaisuuksien ja sisällön ymmärtämistä. Useimmat digitaalisista palveluista ovat suomenkielisiä, joskus myös ruotsin- ja englanninkielisiä, ja sanastoltaan vaativia.

Maahanmuuttajien verkkopalvelujen käyttöä hankaloittaa heikkojen tietoteknisten taitojen lisäksi sisältöjen suunnittelu valtakulttuurin ehdoilla. Toteuttamissamme hanketoimijoiden haastatteluissa tuotiin esiin, että maahanmuuttajan kohtalainenkaan kielitaito ei riitä digitaalisten palveluiden käyttöön ja 
ymmärtämiseen, jos palvelun termistö painottuu virastokieleen tai ainoastaan tietojärjestelmissä yleisiin käsitteisiin. Toisaalta esimerkiksi työelämässä käytettävä termistö ei riitä yhteiskunnalliseen osallistumiseen suunnattuja verkkopalveluja käytettäessä.

Kansainvälisen PIAAC-aikuistutkimuksen (The Programme for the International Assessment of Adult Competencies) mukaan noin 11 prosentilla Suomen 16-65-vuotiaasta aikuisväestöstä on hyvin heikot tietotekniikkaa soveltavat ongelmanratkaisutaidot. Jos mukaan lasketaan PIAAC:n testissä tietokoneen käytöstä kieltäytyneet ja heikot taidot omaavat henkilöt, jopa 30 prosenttia eli noin miljoona aikuista omaa puutteelliset tietotekniikan soveltamisen taidot. Ikä ja koulutus ovat merkittävimpiä taitojen kanssa korreloivia tekijöitä. Iäkkäimpien lisäksi toisena selkeänä joukkona ovat ensimmäisen sukupolven maahanmuuttajat. (PIAAC 2012; 2015.)

PIAAC-tutkimuksen maahanmuuttajataustaisten henkilöiden pienehköstä lukumäärästä huolimatta (229 henkilöä 5464 kokonaismäärästä) tutkimus kertoo sekä perustaitojen (luku-, numero- ja TVTtaidot) heikkouksista (noin 40 prosentilla vastaajista) että kielitaidon merkityksestä perustaitojen hallinnassa. Tutkimuksen jälkeen turvapaikanhakijoiden määrä on kasvanut, joten myös perustaitojen puutosten voi olettaa ratkaisevasti kasvaneen. Tammi-maaliskuussa 2016 vastaanottokeskuksissa tehdyn osaamiskartoituksen mukaan 7 prosentilla turvapaikanhakijoista ei ollut lainkaan luku- tai kirjoitustaitoa omalla äidinkielellään ja 73 prosenttia tarvitsee harjoitusta latinalaisella kirjaimistolla lukemisessa ja kirjoittamisessa (Sandberg \& Stordell 2016).

Aiemman tutkimuksen ja keväällä 2016 tekemiemme haastattelujen perusteella maahanmuuttajien taitotaso on hyvin vaihtelevaa erityisesti koulutustaustasta, iästä ja maahanmuuton syistä riippuen. Perinteisesti suurin maahanmuuttajien ryhmä koostuu kouluttautuneista venäläisistä ja virolaisista, joiden maahanmuuton syitä ovat yleisimmin opiskelu, työ ja perhesuhteet (Maahanmuuttovirasto 2015).

Turvapaikanhakijoina Suomeen saapuneista suurimmat ryhmät ovat tulleet Somaliasta ja Irakista, ja heistä somalialaisten koulutustaso on yleensä alhaisempi. Heikoimpien valmiuksien riskiryhmiin kuu- luvat kouluttamattomat turvapaikanhakijoina tulleet, iäkkäät sekä Lähi-Idästä ja Afrikasta kotoisin olevat naiset. Ilman koulutuksellista erityistukea näiden ryhmien integroituminen uuteen yhteiskuntaan vaikeutuu ja mahdollisesti estyy (esim. PIAAC 2015).

Syyt ja seuraukset nivoutuvat toisiinsa: heikot taitovalmiudet johtavat vaikeuksiin opiskelupaikan saamisessa, jatko-opiskelussa, työhön sijoittumisessa ja erityisesti työllistymisessä paikkaan, jossa taitoja voi edelleen kehittää. Hyvät taitovalmiudet puolestaan saavat aikaan positiivisen kierteen. Koulutetut vanhemmat tarjoavat lapsilleen myös uudessa maassa usein paremmat edellytykset taitojen kehittämiseen, jolloin valmiudet periytyvät. Maahanmuuttajien ensimmäisen sukupolven taitovalmiuksien kehittäminen on siis tärkeää myös toisen polven maahanmuuttajien integroitumisen onnistumiseksi.

Haastattelimme keväällä 2016 kahden Taito-ohjelman hankkeen, maahanmuuttajien koulutuksen sekä järjestöjen edustajia (yhteensä 15 henkilöä). Haastattelemamme hanketoimijat sekä maahanmuuttajien opettajat pyrkivät maahanmuuttajien digitaalisten valmiuksien lisäämiseen sekä maahanmuuttajakoulutusten pedagogisten mallien kehittämiseen. Ryhmähaastatteluihin osallistuivat kahden Taito-ohjelmaan kuuluvan hankkeen koordinaattorit, projektipäälikkö, projektityöntekijä, kaksi maahanmuuttajaa sekä maahanmuuttajien opettajia Luksian aikuisopistossa ja Kouvolan aikuiskoulutuskeskuksessa ( 8 henkilöä). Lisäksi haastattelimme Tampereen aikuiskoulutuskeskuksen kotoutumiskoulutuksen opettajia (3 henkilön ryhmähaastattelu) ja tutustuimme kahteen järjestöjen käynnistämään kotoutumista tukevaan toimintamuotoon Espoossa ja Tampereella (4 henkilöä).

Haastatteluaiheiston analysoinnilla olemme selvittäneet maahanmuuttajien tietotekniikan soveltamiseen liittyviä haasteita sekä hankkeiden ehdotuksia näiden ylittämiseksi. Menetelmänä olemme käyttäneet osallistuvaa havainnointia toiminnallisissa hankkeissa, joissa olemme keskittyneet erityisesti taitopuutosten tunnistamiseen, hankkeissa mahdollisesti tapahtuviin muutosprosesseihin ja käytäntöjen uudistamiseen.

Teoreettisena viitekehyksenämme on konstruktivistinen oppimiskäsitys, jossa oppiminen 
on prosessinomaista, oppijakeskeistä sekä vuorovaikutteista (Berger \& Luckman 1994). Tärkeänä ajatusmallinamme on sosiokulttuurinen näkemys oppimiseen, mikä korostaa oppimisen kulttuurisidonnaisuutta (Vygotsky 1978). Digitalisoituvassa kulttuuriympäristössä on huomioitava lisäksi verkostojen ja yhteistoiminnallisen oppimisen merkitys (Siemens 2004).

\section{TIETOTEKNIIKAN KÄYTÖN \\ DELEGOIMISESTA VERTAISOPPIMISEEN}

Nuoret omaksuvat usein vanhempiaan nopeammin digitaaliset käyttöliittymät, ja ohjeistavat myös heitä uusien palvelujen käyttöönotossa. Kuitenkin luonteeltaan henkilökohtaisten tai aikuisille suunnattujen palveluiden, kuten pankki-, työvoima- tai terveydenhoitopalvelut, pitäisi olla vastuullisten vanhempien hallinnassa. Haastattelujemme mukaan maahanmuuttajatyössä on huomattu, että alaikäiset joutuvat esimerkiksi koulun ja huoltajan vuorovaikutukseen tarkoitetun järjestelmän pääkäyttäjiksi.

"Vanhempien tunnukset voidaan lisätä lasten kännykkään ja lapset hoitaa omat poissaolonsa Wilmaan. Vanhemmat eivät tiedä mitä koulussa tapahtuu ja lapsi voi hyödyntää tilannetta. Lasten ei pitäisi hoitaa näitä asioita vanhempien puolesta - -"

(Osallisena verkossa -hankkeen toteuttaja)

Saraleena Aarnitaival on tarkastellut väitöstutkimuksessaan maahanmuuttajanaisten (kurdien ja venäläisten) kotoutumista suomalaiseen työelämään tietokäytäntöjen näkökulmasta. Aarnitaival havaitsi, että erityisesti kotoutumisen alkuvaiheessa naiset delegoivat tiedonhankintaansa kohdemaan kieltä paremmin osaaville. Tiedonhankkijoina ovat usein perheenjäsenet, sukulaiset ja omaan etniseen ryhmään kuuluvat ystävät. (Aarnitaival 2012.) Tällaisten vaativien tehtävien delegointi mainittiin myös toteuttamissamme maahanmuuttajatyötä tekevien ryhmähaastatteluissa.

Taitojen hallintaa on hyödyllistä tarkastella sosiokulttuurisessa kehyksessä. Suomessa monet maahanmuuttajat tulevat yhteisöllisistä kulttuureista, joissa asioiden jakaminen on luontevampaa kuin yksilölli- nen omistaminen. Yhteisöllisessä kulttuurissa kylän yhdenkin henkilön luku- tai kirjoitustaito, samoin kuin tietokone ja sen käyttämiseen tarvittavat taidot, voi riittää koko kylän tarpeiksi. Yhteisöllisen jakamisen kulttuuri voi esimerkiksi vaikuttaa maahanmuuttajanaisten opiskelumotivaatiota heikentävästi, jos perheen päätöksenteko ja talous ovat vain miehen hallinnassa eikä tarpeita perheenäidin kouluttautumiselle näytä olevan (H3).

Useiden tutkimusten mukaan vähän koulutetut maahanmuuttajanaiset ja perheenäidit ovat marginalisoitumisen riskiryhmässä, koska he jäävät miehiä helpommin työelämän ja perhettä laajempien sosiaalisten verkostojen ulkopuolelle (Martikainen \& Tiilikainen 2007; Aarnitaival 2012; Sutela 2015). Heikot verkostot voivat hankaloittaa esimerkiksi työnhakua (Siemens 2004). Ilmiö voi jarruttaa paitsi naisten integroitumista uuteen kotimaahan, myös lasten myöhempää elämää. Tutkimuksen mukaan vielä toisen sukupolven maahanmuuttajien koulumenestys on selvästi kantaväestöä heikompaa, mikäli vanhempien koulutustaso on matala (esim. Harju-Luukkainen ym. 2014).

Yhteisöllisen kulttuurin voi nähdä edesauttavan jäsentensä kouluttautumista, jos yhteisö on sitä tukemassa. Tiedon ja taitojen jakamiseen yhteisöllisessä kulttuurissa kuuluu lisäksi velvollisuus toimia yhteisön jäsenten opettajana, mikä edesauttaa vertaisoppimista ja konstruktiivista sosiaalisissa tilanteissa tapahtuvaa tiedonmuodostusta. (Tammelin-Laine 2014; Berger \& Luckmann 1994.) Erityisesti maahanmuuttajanaisten kotoutumisen edistämiseksi onkin syntynyt useita hankkeita, jotka tarjoavat naisille kohtaamispaikkoja, koulutuksia ja neuvontaa. Esimerkiksi Monika-Naisten Liitto, Naistari ja Luetaan yhdessä -lukupiiri pyrkivät naisten osallistamiseen ja voimaannuttamiseen eri kulttuureista tulevien naisten vertaisryhmissä. Hankkeissa on huomattu, että digitaalinen osaaminen on tärkeää kotoutumisessa. Monika-Naisten ehdotuksessa Työ-ja elinkeinoministeriölle (2016) todetaan:

"Osalle maahanmuuttajataustaisista naisista tietokoneen käyttötaito on erittäin heikko tai olematon. Kyvyttömyys käyttää tietotekniikkaa hidastaa ko- 
toutumista ja aiheuttaa syrjäytymistä sekä peruspalvelujen ja-tietojen ulkopuolelle jäämistä."

Monikulttuuristen naisten kohtaamispaikassa kokemukset osoittavat, että tietotekniikan opetus on monesti aloitettava perusteista kuten ruudunlukutaidoista. Monikulttuurisessa tilassa naiset tukevat ja opettavat toisiaan. Kohtaamispaikka on eräänlainen yhteiskunnan kolmas tila, joka mahdollistaa turvallisen paikan sosiaaliselle verkottumiselle, kommunikoinnille sekä vertaisoppimiselle.

\section{KIELENOPETUSTA JA TIETOTEKNISIÄ}

\section{TAITOJA RINNAKKAIN}

Kielenopetus osoitetaan yleensä ratkaisevan tärkeäksi kotoutumisprosessin alkuvaiheessa (Opetushallitus 2012), ja havaintoa tukee myös aikuisten maahanmuuttajien perustaitoja koskeva tutkimus (esim. Tammelin-Laine 2014). Tutkimusta muista kuin koulutetuista mahanmuuttajista on Suomessa tehty erittäin vähän, eikä tutkimusta tietoteknistyneeseen yhteiskuntaan liittyvistä haasteista selvityksemme mukaan ole olemassa.

Kun heikot taitovalmiudet merkitsevät yhtä aikaa kielitaidottomuutta ja tietoteknistä osaamattomuutta, voidaan kysyä pitäisikö koulutus aloittaa kielenopetuksesta vai tieto-ja viestintätekniikan taidoista.

Opetushallituksen suosituksen mukaan koulutuksessa tulisi integroida suomen kieltä, arjen taitoja, elämänhallintaa, yhteiskunta- ja kulttuuritietoutta sekä työelämä- ja opiskeluvalmiuksia (OPH 2012). Käytännöissä on yleensä kaksi toimintatapaa: tietotekniikkaa käytetään suomen kielen opiskelun apuna ja tukena tai sitä opetetaan rinnakkain suomen kielen kanssa. Aikuisten kotoutumiskoulutuksen sisältöalueita ovat suomen kieli ja viestintätaidot, työelämätaidot, yhteiskunnalliset taidot, tietotekniset taidot ja opiskelutaidot (esim. TAKK 2016).

Kouluttaja voi aloittaa suomen kielen opetuksesta ja sisällyttää tietotekniset taidot opetukseen vasta myöhemmin. Jos tietotekniikka kuitenkin otetaan opetukseen heti alussa, suhtautuminen teknologiaan voi muodostua luontevammaksi ja myönteisemmäksi.

Osa haastattelemistamme hanketoimijoista suo- sittelee tietotekniikan käyttöönottoa vielä Suomen kieltä taitamattomien ohjaamisessa. Tätä puoltaa paitsi viranomaispalveluiden digitaalisuus, myös tiedonhaun ja sosiaalisen verkostoitumisen mahdollistuminen. Monet sosiaalisen median palveluista ovat helppokäyttöisiä ja käyttöönotto ei useinkaan vaadi juuri kielitaitoa. Esimerkiksi Luksian aikuisopiston kotoutumiskoulutuksessa on kokeiltu yhteisöllisten sovellusten kuten WhatsAppin ja Facebookin käyttämistä koulutusryhmien viestintävälineenä.

Nykyisen yhteiskuntamme sosiokulttuurisessa viitekehyksessä tuskin voidaan puhua kieli-ja lukutaidosta ilman media- tai informaatiolukutaidon käsitettä. Oppimisen näkökulmasta huomio kiinnittyy tällöin sosiaalisiin oppimisprosesseihin ja informaatiolähteisiin sekä tietoteknologiaan osana oppimisprosesseja (Korhonen 2008). Vaikka tiedonmuodostus näyttäytyy nykyisin globaalina, kieli- ja lukutaidoilla sekä teknologian roolilla viestinnässä on kulttuuriset eronsa. Lev Vygotskyn mukaan kieli ja ihmisten sosiaaliset suhteet määrittävät tiedonmuodostusta. Lisäksi ihmiset toimivat aina kulttuuristen työkalujen (esim. toimintatavat tai nykyisin tietotekniikka) välityksellä, ja niiden käyttö ja tarkoitus opitaan sosiaalisessa vuorovaikutuksessa. (Vygotsky 1978.)

Nykyisin useimmille kolmansista maista saapuville maahanmuuttajille informaatioympäristöön kuuluvat esimerkiksi älypuhelimet. Heille tietotekniikan soveltaminen on tutumpaa mobiililaitteilla kuin tietokoneilla. Tämä teknologinen loikkaaminen eli niin sanottu leapfrogging on ollut tyypillistä monissa kehittyvissä maissa, joissa tietotekniikan soveltaminen on yleistynyt vasta uuden teknisen ratkaisun eli mobiiliteknologian ansiosta.

Tietotekniikan käytön sekä informaatiolukutaidon haasteisiin voidaan vastata sekä koulutuksilla että käyttöliittymäsuunnittelulla. Digitaalisten taitojen ja kielitaidon rinnakkaiseen opiskeluun on kehitetty esimerkiksi Opetushallituksen ylläpitämä Kotisuomessa.fi-verkkopalvelu. Sivustolla suomen ja ruotsin kielen opiskelu on yhdistetty kulttuuriin ja yhteiskuntaan tutustumiseen sekä tietokoneen käytön perusteisiin. Havainnollinen ja helppokäyttöinen sivusto on suunniteltu aikuisille itsenäisen opiskelun 
apuvälineeksi. Sivustolla huomio kiinnittyy selkeään visuaalisuuteen, mikä helpottanee käyttöä myös niille, joille tietokone käyttöliittymänä on vielä vieras.

\section{PEDAGOGISIA MALLEJA}

\section{JA SELKEITÄ KÄYTTÖLIITTYMIÄ}

Maahanmuuttajien koulutuksen tavoitteena on antaa Suomeen muuttaville valmiuksia toimia tasavertaisina jäseninä suomalaisessa yhteiskunnassa (Opetushallitus 2012). Aikuisten maahanmuuttajien kotoutumiskoulutusta järjestetään sekä työvoimapoliittisena että omaehtoisena koulutuksena. Koulutuksia järjestävät paikalliset aikuiskoulutuskeskukset sekä TE-toimistot, jotka myös ostavat koulutuksia. Työvoimakoulutuksena toteutettava koulutus ei kuitenkaan saavuta kaikkia, kuten kotonaan lapsia hoitavia vanhempia. Kotiäidit saattavat jäädä kokonaan neuvonta- ja ohjauspalvelujen ulkopuolelle. (OPH 2016.)

Opetus- ja kulttuuriministeriön teettämän selvityksen mukaan järjestelmä ei nykyisellään vastaa maahanmuuttajien puuttuvien perustaitojen opetustarpeisiin. Reitit koulutukseen ja työelämään ovat pitkiä, sisältävät tyhjäkäyntiä, päällekkäisyyksiä ja joskus myös epätarkoituksenmukaisia opintoja. Kotoutumiskoulutukseen pääsyä voi joutua odottamaan. (OKM 2016.) Uusia malleja ja parempia käytäntöjä integroitumisvaiheen koulutukseen haetaankin parhaillaan erilaisissa projekteissa ja pilottihankkeissa, kuten Taito-ohjelman hankkeissa.

Myös kolmannen sektorin tarjoamat palvelut, kuten vapaan sivistystyön koulutukset ja järjestöjen maahanmuuttajatyö, täydentävät usein hyvinkin kriittisiä opetus-ja ohjaustarpeita. Erityisesti kotoutumiskoulutusten ulkopuolelle jääneille maahanmuuttajille nämä voivat olla ainoa väylä puuttuvien perustaitojen hankkimiseen.

Vaikka kotoutumiskoulutukset on jaettu kolmeen eri nopeuksilla etenevään väylään, ryhmien hetero- geenisuus on opettajille hankalaa. Haastatteluissamme todettiin, että tietotekniikan opetustunnilla opettaja tarvitsisi apukäsiä kaikkien erilaisten tilanteiden ohjaamiseen. Muita pedagogisia haasteita ovat opintojen itseohjautuvuus ja erityistuen tarpeet.

Monet aikuiskoulutukset, kuten verkko-opiskelua sisältävät opinnot, vaativat nykyisin opiskelijoilta hyvin itsenäistä suoriutumista. Opiskelua toteutetaan monesti ryhmätyöskentelynä ja vertaisopiskeluna. Suuri osa maahanmuuttajista on kuitenkin saanut koulutuksensa autoritaarisessa koulujärjestelmässä ja behavioristisen oppimiskäsityksen mukaisesti. Aktiivisen ja itsenäisen opiskelun toteuttaminen vaatii erityistä tukea ja oppimiskäsitysten uudelleen määrittämistä. Tukea tarvitaan lisäksi muiden kulttuuristen ristiriitojen ylittämiseksi sekä vaikeista olosuhteista johtuneiden traumojen hoitamiseksi. Erityistuen tarpeet aiheuttavat oppilaitoksille kasvavia vaatimuksia.

Kouluttajien ohjausosaamisen kehittäminen on yksi tarjotuista pedagogisista ratkaisuista. Esimerkiksi Kouvolan aikuiskoulutuskeskuksen toteuttamassa hankkeessa on kehitteillä ratkaisukeskeinen ohjausmalli, jossa korostuvat opiskelijoiden yksilölliset tarpeet ja heikoimpien opiskeluvalmiuksien parantaminen. Malliin sisältyy opiskelijoiden perustaitoja kehittävä (PUHTI - Ohjauksen tahto ja taito) valmennus sekä kouluttajien ohjausosaamisen lisääminen esimerkiksi monialaisella verkostoyhteistyöllä. Valmennus ja ohjauksen toimintamalli pyrkivät vastaamaan erityistuen tarpeisiin, jotka aiheutuvat heikoista perusvalmiuksista tai muista opiskelua jarruttavista tekijöistä.

Kouluttajien on otettava huomioon, että kohderyhmän osaamisessa voi olla suuria tasovaihteluita. On mahdollista, että tieto- ja viestintäteknologinen kokemus rajoittuu vain yksittäisen pikaviestin- tai yhteisöpalvelun mobiilikäyttöön. Osaamisessa saattaa olla vielä tätäkin suurempia puutteita, jolloin esimerkiksi kaikki tietokoneympäristöön liittyvät asiat ovat oppijoille entuudestaan vieraita. 
Maahanmuuttajaryhmien parissa toimivat haastateltavat ovat kokeneet yksinkertaiset ja tietokonekäytössä vakiintuneet käyttöliittymät kaikkein toimivimmiksi. On olennaista keskittyä arkielämän kysymyksiin, jolloin oppimisen tarkoitus ja sen mukanaan tuleva hyöty ovat konkretisoituvat. Lisäksi erilaisten tukihenkilöiden, kuten tutorien läsnäolo on tärkeää varsinkin silloin, kun sovellusta käytetään ensimmäisiä kertoja.

\section{DIGITAALISET MATERIAALIT OPPIMISEN TUKENA}

Maahanmuuttajille on tarjolla runsaasti digitaalisia oppimateriaaleja esimerkiksi kielen oppimiseen. Hanna Tani (2008) kävi selvityksessään läpi 76 aikuisille maahanmuuttajille soveltuvaa suomen kielen sähköistä oppimateriaalia. Selvityksestä ilmeni, että materiaalien käyttö edellyttää itseohjautuvuutta, sillä ne ovat käyttöominaisuuksiltaan erilaisia ja niiden itsenäinen käyttö vaatii jo suhteellisen hyvää suomen kielen taitoa. Vaikka Tanin selvitys on jo vuodelta 2008, ovat monet siinä mainituista materiaaleista edelleen olemassa ja osan sisältöjä myös päivitetään aktiivisesti.

Digitaalisia oppimateriaaleja voidaan arvioida muun muassa pedagogisella, sisällöllisellä ja välineellisellä laatukriteeristöllä (Tani 2006). Nokelainen (2006) tuo puolestaan esiin, että digitaalisen oppimateriaalin arvioinnissa on perinteisesti keskitytty käyttöliittymiin. Arvioinnissa tulee ottaa huomioon myös digitaali- ja verkkoympäristölle ominaiset arviointikriteerit, kuten yhteistoiminnallisuus, palautemahdollisuudet ja sovellettavuus. Shee ja Wang (2008) korostavat, että oppijat kiinnittävät käytettävyyden lisäksi huomiota erityisesti sisältökysymyksiin, kuten päivitettävyyteen. Voimakkaasti yleistyneen yhteisöllisen median mukanaan tuomat käyttömuodot voivat toimia tehokkaasti yhteistoiminnallisissa oppimistilanteissa, vertaistuen kanavina sekä oppimissovellusta eteenpäin jaettaessa.

Kognitiivis-konstruktivistiset oppimisnäkemykset korostuivat erityisesti tietokoneavusteisen oppimisen yhteydessä 1990-luvulla. Oppijan aikaisemmat tiedot ja aktiivinen rooli ymmärryksensä kehittäjänä asettivat myös digitaalisen oppimateriaalin kehittämiselle uusia vaatimuksia. Perinteinen kylläei-valinnoilla etenevä drill-tehtävä koettiin kaavamaisena ja behavioristiseen oppimiskäsitykseen nojaavana (esim. Hung 2001).

Tutkimuksemme valossa yksinkertaista suoritetta mittaavat testit ja esimerkiksi kaupassakäynnin simulaatiot, kuten papu.net-portaalin harjoitukset, vaikuttavat luontevilta maahanmuuttajien käytännön osaamista harjoittaviin tarpeisiin, vaikka niiden mekaniikka perustuu usein behavioristisiin näkemyksiin. Oppijan omaa aktiivisuutta ja aikaisempia tietoja voidaan korostaa yksilöllisillä oppimispoluilla, jolloin oppijalla on mahdollisuus saada oppimisprosessin aikaista palautetta ja tarkkailla omaa etenemistään. Oppija voi myös tallentaa osaamisensa kannalta tärkeiksi katsomiaan informaatiosisältöjä tai oppimistehtävän tuloksia myöhempää käyttöä varten.

\section{KUVIEN KÄYTÖN JA PELILLISTÄMISEN MONET MAHDOLLISUUDET}

Jos maahanmuuttajataustaisilla oppijoilla on heikko lukutaito tai koulutustilanteeseen ei löydy yhteistä kieltä, visuaaliset keinot nousevat tärkeään rooliin tietokoneavusteisissa oppimateriaaleissa. Kuvan rooli voi olla materiaalissa moninainen. Perinteinen keino on käyttää kuvaa tai animaatiota yhdessä tekstin ja mahdollisesti myös kertojaäänen kanssa. Yksittäisen kirjoitetun sanan merkitys täsmentyy kuvan avulla. (Mayer 2009.)

Semioottisesti kuvat voidaan tulkita yhteisesti sovituiksi symboleiksi, jotakin asiaa kuvailmaisullisesti esittäviksi ikoneiksi tai syy-seuraussuhdetta osoittaviksi indeksisiksi kuviksi (Fiske 1993). Oppimateriaalien kehittämisen kannalta ikonien käyttö on suositeltavaa, koska ne ovat olennainen osa tietokoneperustaisia järjestelmiä. Perinteiset tietokoneen käyttöliittymäikonit, kuten roskakori tai sähköpostilaatikkoa esittävä kirjekuori assosioidaan sovelluksiin ja käyttötilanteisiin. Tämän kaltaiset yleismaailmalliset kuvaikonit tulkitaan kohtuullisen yhdenmukaisesti myös ilman tekstiä.

Indeksistä kuvaa ei perustaitojen oppimateriaaleissa ole käytetty kovinkaan paljon. Sillä on kuitenkin runsaasti käyttömahdollisuuksia, koska indeksi- 
seen kuvaan liittyy runsaasti traditioita, jotka eivät ole kulttuurisidonnaisia. Perinteinen indeksisen kuvan esimerkki on jalanjälki hiekassa, mikä viittaa lähimenneisyyteen osoittaen, että kyseisestä kohdasta on kävelty. Tämän tyyppisten kuvien käyttö mahdollistaa tarinallisuuden hyödyntämisen erityisesti alkuvaiheessa, jolloin oppijoiden lukutaito on heikkoa tai yhteistä kieltä ei ole löytynyt.

Myös kuvasymboleita voidaan käyttää, sillä ikonien tavoin ne yleensä vievät vähän tilaa esimerkiksi mobiililaitteen näytöllä. Haittapuolena on se, että toisin kuin indeksiset tai ikoniset kuvat, symbolit edustavat yhteisesti sovittua asiaa yleensä allegorisesti eivätkä siis välttämättä suoraan assosioidu kuvan esittämään asiaan.

Myös äänen käyttö on mahdollista digitaalisissa oppimateriaaleissa. Tekstinä kirjoitetun virkkeen toistaminen auditiivisesti on tyypillinen tapa, mutta tekstinlukuohjelmia voidaan lisätä minkä tahansa tekstin yhteyteen (ks. esim. ReadSpeaker tampere.fi).

Opetuksen pelillistäminen on viime vuosina kohonnut tärkeäksi keskustelunaiheeksi myös digitaalisten oppimateriaalien kehittämisessä, vaikka opetuspelejä on ollut tarjolla jo pitkän aikaa. Flores (2015) esittää, että oppimisen pelillistämistä voi tietokoneympäristössä kokea 1) pelillistetyissä oppimateriaaleissa (Gamification), 2) peliin perustuvassa oppimisessa (Game-based learning) ja 3) simulaatioissa (Simulation).

Pelillistetyssä oppimateriaalissa toiminnan varsinainen kohde on oppiminen, kun taas peliin perustuvassa oppimisessa toiminnan kohteena on pelaaminen ja oppimista tapahtuu sivutuotteena. Simulaatiossa opittua voidaan soveltaa todenkaltaisessa ympäristössä.

Pelillistämisen avulla oppija ja opettaja voivat tarkkailla oppimisprosessin kulkua ja prosessi voi olla perinteistä opiskelua motivoivampaa. Oppijan suoritusten myötä on mahdollista jakaa suoritusmerkkejä, mahdollistaa pääsy vaativammille tasoille tai tietoresursseihin ja lisätä oppijan käyttöoikeuksia (Domínguez ym. 2013). Lähiopetuksessa opettaja voi esimerkiksi jakaa opiskelijaryhmät joukkueisiin ja käydä läpi opittua asiaa verkkopohjaisena tietokilpailuna.
Maahanmuuttajien opetuksessa on tärkeää huomioida opiskelijaryhmän taidolliset valmiudet ymmärtää ja käyttää pelimäisiä elementtejä. Opeteltava asia voi jäädä ainakin osittain sivuroolin, jos huomio suuntautuu varsinaisen pelimekaniikan opetteluun ja käyttämiseen.

\section{PÄÄTELMIÄ}

Tietoteknisten taitojen merkitys kasvaa yhteiskunnassa jatkuvasti. Olisikin hyödyllistä harkita tietoteknisten perustaitojen sisällyttämistä jo maahanmuuttajien alkuvaiheen opetukseen kielenopetuksen rinnalle. Näin tietotekniikan käytöstä muodostuu luontevampi osa kotoutumisprosessia, sillä tietokoneympäristön tuntemus on välttämätöntä myös useissa arkipäivän toiminnoissa. Tietokoneen käynnistysrutiinit ja ruudunlukeminen voivat kuitenkin vaatia runsaasti harjoittelua, jos tietoteknistä osaamista ei ole. Erityistuen tarpeet aiheuttavat oppilaitoksille lisävaatimuksia, ja kouluttajilta odotetaan entistä yksilöllisempää ohjausta.

Digitaalisten verkkopalvelujen käyttämisen opettelusta on saatu hyviä kokemuksia erityisesti silloin, kun ohjauspalveluita on viety maahanmuuttajien kohtauspaikkoihin, kuten luku- tai harrastuspiireihin.

Eri kulttuuritaustoista tulleiden maahanmuuttajien koulutustarpeiden tarkastelu sosiokulttuurisesta näkökulmasta voi laajentaa ymmärrystä opiskelun tavoitteiden asettamisesta ja motivaatiotekijöistä. Erityisesti turvapaikanhakijoina tulleet kouluttamattomat naiset ovat marginalisoitumisen riskiryhmässä ja tarvitsevat erityistukea koulutuksiin osallistumiselleen. Yhteisöllinen ja osallistava vertaisopiskelu toimii yleensä näiden ryhmien perustaitojen kehittämisessä itsenäistä suorittamista paremmin.

Koska ulkomaalaistaustaisten naisten työllistyminen on miesten työllistymistä heikompaa, huomiota olisi kiinnitettävä lisäksi naisten sosiaaliseen verkostoitumiseen esimerkiksi järjestämällä monikulttuurisia oppimisen tiloja ja tilanteita kantaväestön naisten ja maahanmuuttajanaisten vuorovaikutukselle.

Maahanmuuttajille on tarjolla runsaasti digitaalisia oppimateriaaleja, mutta kouluttajien ja ohjaajien tulisi perehtyä materiaalien sisältöihin oppimista- 
voitteiden kannalta. Usein tärkeimmiksi tavoitteiksi nousevat maahanmuuttajien arkielämään liittyviin tarpeisiin vastaaminen, esimerkiksi työllistyminen tai lasten koulunkäynnin seuraaminen. Digitaalisissa materiaaleissa äänen ja kuvien käyttö sekä pelillistäminen tarjoavat vielä hyödyntämättömiä mahdollisuuksia, kun halutaan tukea perustaitojen kehittämistä kulttuuritaustasta riippumatta.
Maarit Mäkinen

YTT, tutkija

Informaatiotieteiden yksikkö

Tampereen yliopisto

Mika Sihvonen

FL, tutkija

Informaatiotieteiden yksikkö

Tampereen yliopisto

\section{LÄHTEET}

\section{Kirjalliset lähteet}

Aarnitaival, S. (2012). Maahanmuuttajanaiset työelämätietoa etsimässä. Tutkimus kotoutumisen tietokäytännöistä. Väitöskirjatyö. Tampere: TamPub.

Berger, P. \& Luckmann, T. (1994/1966). Todellisuuden sosiaalinen rakentuminen. Tiedonsosiologinen tutkielma. Helsinki: Gaudeamus.

Domínguez, A., Saenz-de-Navarrete, J., De-Marcos, L., Fernández-Sanz, L., Pagés, C., \& Martínez-Herráiz, J. J. (2013). Gamifying learning experiences: Practical implications and outcomes. Computers \& Education 63, 380-392.

Fiske, J. (1993). Merkkien kieli. Johdatus viestinnän tutkimiseen. Tampere: Vastapaino.

Flores, J. F. F. (2015). Using Gamification to Enhance Second Language Learning. Digital Education Review 27, 32-54.

Harju-Luukkainen H., Nissinen K., Sulkunen S., Suni M. \& Vettenranta J. (2014). Avaimet osaamiseen ja tulevaisuuteen. Selvitys maahanmuuttajataustaisten nuorten osaamisesta ja siihen liittyvistä taustatekijöistä PISA 2012 -tutkimuksessa. Jyväskylä: Jyväskylän yliopiston koulutuksen tutkimuslaitos.

Hung, D. (2001). Theories of learning and computermediated instructional technologies. Educational Media International 38(4), 281-287.

Korhonen, V. (2008). Kohti dialogista lukutaitoa - Oppimisen yhteisöllisiä tietokäytäntöjä ja suhdeverkostoja tunnistamassa. Teoksessa Sormunen \& Poikola (toim.) Informaatio, informaatiolukutaito ja oppiminen. Tampere: Tampere University Press.

Krauss, J. (2012). Infographics: More than Words Can Say. Learning \& leading with Technology 39(5), 10-14.

Maahanmuuttovirasto (2015). http://www.migri.fi/ tietoa_virastosta/tilastot (luettu 1.6.16).
Martikainen, T. \& Tiilikainen, M. (toim.) (2007). Maahanmuuttajanaiset: kotoutuminen, perhe ja työ. Väestöntutkimuslaitoksen julkaisusarja D 46. Helsinki: Väestöliitto.

Mayer, R. E. (2009). Multimedia learning. Cambridge University Press.

Monika-Naiset (2016). Monika-Naisten ehdotus Työ-ja elinkeinoministeriö/le 19.2.16: http://monikanaiset.fi/ tiedotteet/1312/ (luettu 15.5.2016).

Nokelainen, P. (2006). An empirical assessment of pedagogical usability criteria for digital learning material with elementary school students. Journal of Educational Technology \& Society 9(2), 178-197.

OKM (2016). Maahanmuuttajien koulutuspolut ja integrointi - kipupisteet ja toimenpide-esitykset. Opetus- ja kulttuuriministeriön julkaisuja 2016:1.

OPH (2012). Aikuisten maahanmuuttajien kotoutumiskoulutuksen opetussuunnitelman perusteet. 2012:1. Tampere. www.oph.fi/julkaisut (luettu 15.5.2016).

PIAAC (2015). The Programme for the International Assessment of Adult Competencies. OECD Skills Studies. Data Policy Reviews of Adult Skills. Finland. Preliminary version.

PIAAC (2012). Kansainvälisen aikuistutkimuksen ensituloksia. Opetus - ja kulttuuriministeriön julkaisuja 2013:19.

Pirinen, T. (toim.) (2015). Maahanmuuttajataustaiset oppijat suomalaisessa koulutusjärjestelmässä. Helsinki: Kansallinen koulutuksen arviointikeskus.

Sandberg T. \& Stordell E. (2016). Vastaanottokeskuksissa toteutettu alkuvaiheen osaamisen tunnistaminen. Opetus-ja kulttuuriministeriön teettämä osaamiskartoitus: http://www.minedu.fi/export/sites/ default/OPM/Koulutus/artikkelit/maahanmuuttajien_ koulutuksen_kehittaeminen/VOK-raportti_21032016. pdf (luettu 1.6.2016). 
Shee, D. Y., \& Wang, Y. S. (2008). Multi-criteria evaluation of the web-based e-learning system: A methodology based on learner satisfaction and its applications. Computers \& Education 50(3), 894-905.

Siemens, G. (2004). Connectivistm: A Learning Theory for the Digital Age. Elearnspace: http://www. elearnspace.org/Articles/connectivism.htm (luettu 23.5.2016)

Sutela, H. (2015). Ulkomaalaistaustaiset työelämässä. Ulkomaista syntyperää olevien työ ja hyvinvointi -tutkimus 2014. Tilastokeskus: www.stat.fi/tup/ maahanmuutto/art 2015-12-17-003.html (luettu 23.5.2016).

TAKK (2016). www.takk.fi (luettu 25.4.2016).

Tammelin-Laine, T. (2014). Aletaan alusta. Luku- ja kirjoitustaidottomat aikuiset uutta kieltä oppimassa. Väitöskirja. Jyväskylä: Jyväskylän yliopisto.

Tani, H. (2008). Selvitys aikuisten maahanmuuttajien suomen kielen sähköisen materiaalin tarjonnasta ja saatavuudesta. Opetushallitus: Helsinki.

Vygotsky L., S. (1978). Mind in Society. The Development of Higher Psykological Processes. Cambridge: Harvard University Press.

\section{Haastattelut}

Osallisena verkossa -hankkeen toimijoiden haastattelut Espoon kirjastossa ja Luksian aikuisopistossa 17. helmikuuta 2016. Ryhmähaastatteluihin osallistuivat hankkeen projektipäällikkö, projektityöntekijä, vapaaehtoistyöntekijä sekä maahanmuuttaja.

PUHTI - ohjauksen tahto ja taito -hankkeen toteuttajien haastattelu Kouvolan aikuiskoulutuskeskuksessa 19. helmikuuta 2016. Ryhmähaastattelussa hankkeen projektipäällikkö sekä toteuttavat opettajat.

Tampereen aikuiskoulutuskeskuksen kotoutumiskoulutuksen toteuttajien haastattelu Tampereella 21. maaliskuuta 2016. Ryhmähaastatteluun osallistui kolme opettajaa.

Kansainvälisen naisten tapaamispaikan toimijoiden haastattelu 30. maaliskuuta Tampereella 2016. Ryhmähaastatteluun osallistui yksikön johtaja, harjoittelija sekä kaksi maahanmuuttajaa. 